\title{
The Use Of Technology To Improve The Delivery Of Advanced Accounting Course In The United Arab Emirates University
}

Mohamed H. Abdel-Azim, (Email: Mohamed.hassan@uaeu.ac.ea), United Arab Emirates University, United Arab Emirates

\begin{abstract}
The College of Business and Economics (CBE) in the United Arab Emirates University (UAEU) got the accreditation of the Association to Advance Collegiate Schools of Business (AACSB) by the end of 2000. Since then, there have been several educational and academic changes in the CBE policy and operational strategies. One of the significant changes was the development of course delivery approach towards active learning based on the utilization of technology and web based education. During the period 2001 to 2005, the accounting department developed 60\% of its courses to be delivered according to the new approach. This paper reports how the course "Advanced Accounting" was traditionally delivered and the changes applied to get the benefits of technology in order to improve our students' skills. The paper also reports the effect of that change on the education outcome measured in two sets of variables. The first measures the changes in students' course evaluation and the second measures the changes in students' performance before and after the course development. A conclusion is made on the effect of web based education and the use of technology on the accounting education.
\end{abstract}

\section{THE TRADITIONAL APPROACH TO DELIVER THE “ADVANCED ACCOUNTING” COURSE}

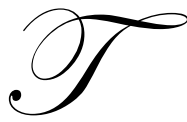

his course covers the conceptual basis and practical aspects of accounting for some companies. It focuses on financial accounting and reporting in the following topical areas: business combinations; consolidated financial statements; foreign currency transactions; translation of financial statements of foreign affiliates; and corporate reorganization and liquidation.

Before the development, a traditional teaching approach was used to deliver this course where students had a passive role in the learning process and the instructor had to impart knowledge to students. There was no use of the technology in students-instructor, or the students-students communications. Students were not required to use the Internet to search for accounting pronouncements related to the course topics. The main tool used for students' performance evaluation was traditional exams which covered more than $80 \%$ of the total course grade.

Many researchers have suggested that passive instruction through lecture is not an effective teaching mode (Ashraf, 2004, Bartlett 1995a, 1995b; Batra, Walvoord, \& Krishnan, 1997; Bowen, Clark, Holloway, \& Wheelwright, 1994; Comer, 1995; Kerr, 1983; McCorkle, Diriker, \& Alexander, 1992; McKinney \& Graham-Buxton, 1993; Moore, 1998; Rau \& Heyl, 1990; Strong \& Anderson, 1990; Williams, Beard, \& Rymer, 1991).

\section{THE NEW METHODOLOGY TO DELIVER THE COURSE}

Starting 2001, the accounting department in the UAEU began to change and develop the approach used to deliver all the accounting courses offered by the CBE. This change was according to the CBE policy to enforce the active learning methodology and E-learning environment.

The development of this course was completed in the winter vacation of the academic year 2003-2004. The development process was based on the use of specific active learning techniques in the course delivery. These 
techniques include (1) engaged learning; (2) cooperative learning; (3) case-based learning; and (4) project-based learning.

\section{Engaged Learning}

Students' participation became of a great importance, the learning process was changed to be student centered rather than instructor centered. Students became required to prepare for each class in advance. They are now required to participate in a discussion of home assignments at the beginning of each class; make short presentation of the new class topic in some classes; take online quizzes at the beginning of most classes; and solve in classroom exercises and problems. Students are also required to navigate the Internet to explore the accounting pronouncements related to each of the course topics. For each of the course topics, some materials are downloaded from the book web site and from many other book sites, some materials are edited, and some materials are developed specially exercise and problem excel files. The developed excel files help students solve assignments and send them electronically using the digital drop box tool of the black board.

To test students' advance preparation for each class, they are required to be prepared to have an opening online quiz in all lectures. In lectures that don't start with a quiz, some of the students are asked to make short presentations of the lecture topic. All quizzes are uploaded to the course BB site.

Some of the accounting standards setting organizations are determined for students to navigate and explore by the end of each chapter. Links to the web sites of these organizations are uploaded to the course BB site. In addition to these links, students are encouraged to use the university library data bases to search for recent articles related to the course topics.

\section{Cooperative Learning}

In a cooperative learning environment, group goals motivate students to help each other because the success of the group depends on the success of the individual members. Cooperative learning promotes higher achievement than methods in which students work competitively or individualistically. Students experience greater retention of information, increased motivation to achieve, higher levels of cognitive thinking, and enhanced learning (Akan, 2005; Johnson, Johnson, Holubec, \& Roy, 1984). Individual mastery of concepts is required in cooperative learning.

The basic conditions for cooperative learning include a group goal, individual accountability, and group accountability (Slavin, 1988). Cooperative learning is based on five interdependent elements (Slavin, 1988). First, group members must be aware of their interdependence, and their goals must be common to all. Second, there must be verbal interaction. Students must explain, support, relate, and convince others. Third, the learning of each individual must be monitored and ensured. Fourth, for the groups to accomplish their goals, trust building, communication skills, leadership, and conflict resolution skills must be operative. Finally, the group must be heterogeneously assembled to accommodate high, average, and low abilities.

After the course development, students of each class are divided to heterogeneous groups (members of each group will be selected randomly). Members of each group work together to prepare for class presentations; solve group case studies; and prepare an ongoing project over the whole term.

\section{Case-Based Learning}

Case-based teaching methods use cases or problems as anchors for learning. Students are presented with complex and real-world problems or cases and asked to analyze and solve these problems through reflection and discussion (Allen, Otto, \& Hoffman, 2000; Dabbagh \& Denisar, 2005). According to Welty (1989), the key to casebased teaching is the discussion itself, through which students "learn to identify actual problems, to recognize the key players and their agendas, and to become aware of those aspects of the situation that contribute to the problem". 
Benefits of case-based teaching methods for instructional design students include helping students: (a) draw connections between their emerging knowledge of instructional design and the complex demands of practice, (b) reflect on relevant theory and methods as they explore a greater number of design issues in a broader array of contexts, and (c) broaden their knowledge base as they collaborate with colleagues to identify effective design solutions (Stepich et al., 2001).

In the course development process, a set of cases were determined for each topic. Some of them are to be solved in classroom by student groups, and some more will be solved individually and answers will be submitted through the digital drop box.

\section{Project-Based Learning}

Various teaching and learning benefits of group projects have been discussed in the business pedagogical literature. Some of the benefits that reportedly have accrued to students include cooperative and peer learning, peer modeling, teamwork, and efficiency. The benefits that presumably accrue to professors, according to the literature, include fewer papers to grade and the freedom to assign more comprehensive projects (Ashraf, 2004).

On the other hand, the literature indicates several disadvantages resulting from the practice of assigning group projects in a classroom setting: the possibility of free riding; high transaction costs - especially if students are commuting from different places or have inflexible schedules because of other obligations (e.g., family, work); poor product quality; stifled individual creativity resulting from within-group dynamics; and poorly structured projects, which may result in delays.

A number of researchers have examined learning in relation to business simulations. The results regarding the effectiveness of simulations as a tool for enhancing learning in the classroom and other pedagogical environments are mixed (Chapman \& Sorge, 1999; Washbush \& Gosen, 2001; Wolfe, 1997). Although the link between simulation performance and learning is not clear, there is considerable evidence that the understanding of management concepts is enhanced when simulations are used as pedagogical tools (Larreche, 1987; Walter et al., 1997; Washbush \& Gosen, 2001; Wolfe, 1997; Wolfe \& Luethge, 2003).

In the course development process, an extended on-going project is used as a basic learning tool. Each group of students is assigned two local companies, one of which is to be considered a parent and the second a subsidiary. Students are required to use the Internet to get the financial statements of their assigned companies from web sites, and all information related to their stock performance from Abu Dhabi and Dubai stock exchange. At the end of each of the course topics, students are required to report a simulation case to apply the topic they learned to their assigned companies. A set of reports was developed to control students' progress in preparation of their ongoing projects.

\section{USES OF TECHNOLOGY IN THE NEW COURSE DELIVERY METHODOLOGY}

Technology has dramatically changed the business environment. In response to this major development, the American Institute of Certified Public Accountants (AICPA, 1998) identified technological adeptness as a key element of the core competencies that graduates will need to become accounting professionals. The AICPA (1999) recommended that the accounting curricula be revised to incorporate information technology. They stated that accounting educators who use technology in their classes help students to both develop technical literacy and master accounting content. Furthermore, in-class use of educational technology helps faculty capture student attention and allows for a greater variety of presentation methods. Students are less bored, more motivated, and likely to learn more (Basile and D'Aquila, 2004).

A recent study on faculty use of instructional technology (Peluchette \& Rust, 2005) concluded that most of the faculty surveyed clearly preferred using some form of technology. They believed that their preferences enhanced their teaching effectiveness, and were comfortable with learning new technologies. The study findings for use of instructional technology methods showed the strongest preference for overhead transparencies and use of overhead 
projector. The next strongest preferences were for "PowerPoint and blackboard or whiteboard". Faculty members demonstrated the least preference for "courses fully online" and "no technology."

In the new course delivery methodology, the course Black Board site is used to make the course materials available to the students before class times, and students use the digital drop box to submit their assignments. The development process included preparation of test pools that were uploaded to the course black board site and used to make on line quizzes at the beginning of some classes to test students' advance preparation of class topics. Students also use data show to make their class presentations based on the power point files that are made available in advance. In addition, students use the Internet to explore the accounting standard setting organizations' web sites and find the latest pronouncements related to the course topics, and to accumulate the required financial information to prepare their projects.

Accordingly, the new methodology to deliver the course requires students' use of laptops both outside and inside the classroom. Outside the classroom, they use the laptop to get the course materials from the course BB site; communicate with each other to solve group assignments through the email, and with the instructor through the digital drop box; and to get financial information related to designated companies to prepare the ongoing projects. Inside the classroom, students use the laptop to take on line quizzes; explore the net to find the latest accounting pronouncements; submit their group case answers; and to take class notes.

\section{LEARNING ACTIVITIES AND THE GRADING POLICY AFTER COURSE DEVELOPMENT}

Application of the new course delivery methodology required the use of new learning activities inside the classroom. Traditionally, all the class time was assigned to staff member lecturing and students had no role in the class other than passive learning. In the developed course delivery approach, students are required to participate in active learning activities that need more than half of the lecture time. The lecture time is planned to be allocated as indicated in the following figure.

Figure 1: Class Time Allocation According To The New Course Delivery Methodology

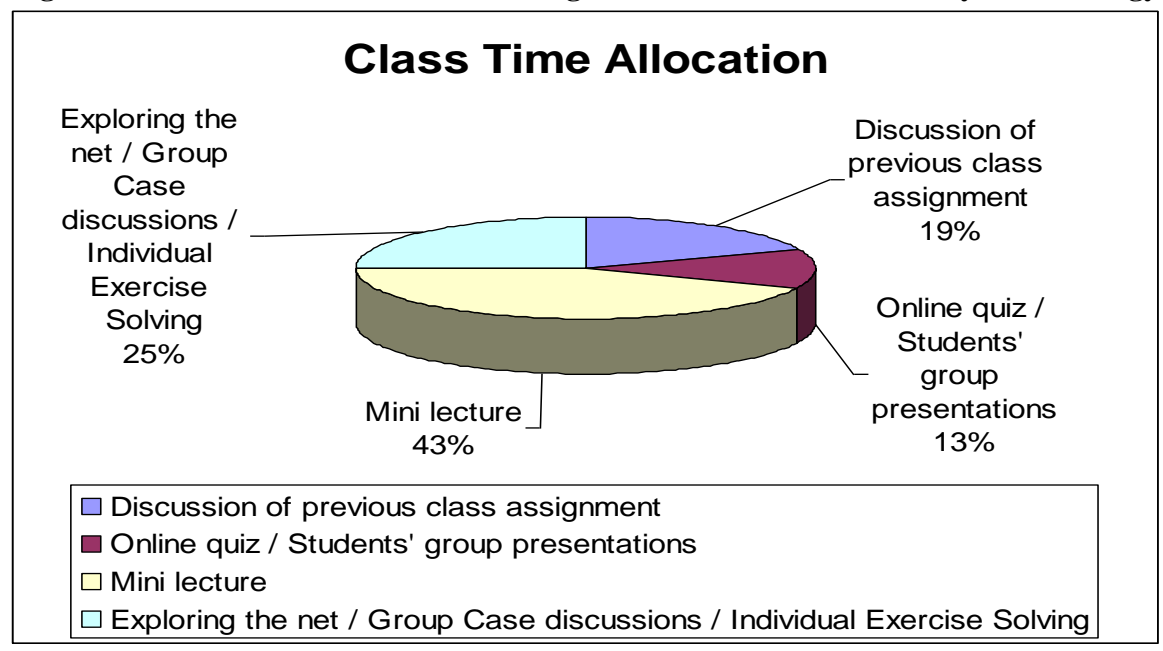

In the new course delivery methodology, at the beginning of each class students will be required to make a discussion of the previous class assignment. Every student should be prepared to participate in this discussion. The role of the instructor in this phase is just to select students based on their assignment answers. The second activity in the class is taking online quiz on the new lecture's topic or making presentations. All students must be prepared for that because they don't know in advance whether they will have a quiz or make a presentation. The last part of the 
lecture also includes students' activity. They have to explore the net to search for accounting pronouncements related to the lecture topic, solve a group case, or solve some individual exercises.

Changes in the course delivery methodology and the in-class learning activities are accompanied by a change in the course grading policy. Traditionally, $15 \%$ of the course grade was assigned to homework and class participation and the remaining $85 \%$ was for written exams. After the course development, the course grading policy is changed as indicated in table 1 below:

Table 1: Grading Policy In The New Course Delivery Methodology

\begin{tabular}{lr}
\hline \hline Computer assignments, and assignment discussions & $10 \%$ \\
Lecture Preparation Quizzes / Students' Presentations & $10 \%$ \\
Group Case discussions & $10 \%$ \\
Individual Exercise/ Case Solving in Class & $10 \%$ \\
Ongoing Project & $10 \%$ \\
Midterm Exam & $15 \%$ \\
Final Exam & $35 \%$ \\
\hline \hline
\end{tabular}

It is shown in table 1 that $\% 50$ of the total course grade is now assigned to the class learning activities. Less emphasis is made on exams, with a greater interest allocated to student class activities.

\section{THE EFFECT OF COURSE DEVELOPMENT ON STUDENT EVALUATIONS AND GRADES}

The use of student evaluations in assessing faculty teaching performance received considerable attention in the literature (Calderon \& Green, 1997, Read, Rama \& Raghunandan, 2001; and Wallace \& Wallace, 1998). Student evaluations, as a tool to evaluate the faculty performance, are criticized in the literature. Many studies argue that these evaluations are not good measures of student learning and that an instructor's gender, age, race, and national origin influence student ratings. Wallace and Wallace (1998) suggested that student evaluations are a measure of students' "happiness index" at the end of a course prior to receiving final grades, rather than a measure of teaching effectiveness. They argued that to the extent that the happiness index reflects workload and grades received, student evaluation results are biased because of the tendency to decrease the former and increase the latter. Table 2 below shows student evaluations before and after the course development.

Table 2 indicates a significant enhancement in student evaluations after the course development. Personal assessment criteria increased by $12.6 \%$ in the average. This set contains six criteria evaluated through the following statements: (1) I prefer to enroll in a different course taught by the same instructor; (2) I have better understood the major, due to studying this course; (3) I was looking forward to studying this course; (4) I did more efforts to study this course than studying other courses; (5) Generally speaking, this course is excellent if compared to other courses; and (6) Generally speaking, the performance of the course instructor has been outstanding.

Students had to give a response on a scale from 1(completely disagree) to 5(Completely Agree). Student evaluations of the three remaining criteria sets also reflected more satisfaction related to the new course delivery methodology. There has been $8.9 \%$ increase in the average evaluation of the criteria related to the text book used. This is in spite of the fact that the same book is used before and after the course development. Students got more benefit because of the new approach used. Student evaluations of the criteria related to assessment techniques and studentinstructor relationship had an increase of $7.8 \%$ and of the criteria related to the instructor had an increase of $7 \%$. 
Table 2: Student Evaluations Before And After The Course Development

\begin{tabular}{|c|c|c|c|c|c|c|}
\hline & \multicolumn{3}{|c|}{$\begin{array}{c}\text { Before } \\
\text { Development }\end{array}$} & \multicolumn{3}{|c|}{$\begin{array}{c}\text { After } \\
\text { Development }\end{array}$} \\
\hline & Female & Male & Total & Female & Male & Total \\
\hline No. of Students Enrolled & 14 & 30 & 44 & 27 & 17 & 44 \\
\hline \multicolumn{7}{|l|}{ Instructor (5 Criteria) } \\
\hline Average & 4.142 & 4.22 & 4.195 & 4.512 & 4.458 & 4.491 \\
\hline Maximum & 4.57 & 4.38 & 4.57 & 4.61 & 4.5 & 4.61 \\
\hline Minimum & 3.71 & 4.10 & 3.71 & 4.39 & 4.36 & 4.36 \\
\hline Std. Deviation & 0.339 & 0.114 & 0.242 & 0.082 & 0.063 & 0.074 \\
\hline \multicolumn{7}{|c|}{ Assessment Techniques and Student-Instructor Relationship (13 Criteria) } \\
\hline Average & 4.111 & 4.1 & 4.1 & 4.466 & 4.347 & 4.42 \\
\hline Maximum & 4.43 & 4.29 & 4.43 & 4.78 & 4.5 & 4.78 \\
\hline Minimum & 3.64 & 3.9 & 3.64 & 4 & 3.64 & 3.64 \\
\hline Std. Deviation & 0.254 & 0.139 & 0.2 & 0.214 & 0.237 & 0.23 \\
\hline \multicolumn{7}{|c|}{ Text Books \& Reference Books, if any (13 Criteria) } \\
\hline Average & 3.918 & 3.821 & 3.85 & 4.187 & 4.208 & 4.195 \\
\hline Maximum & 4.57 & 4.1 & 4.57 & 4.61 & 4.57 & 4.61 \\
\hline Minimum & 2.5 & 3.14 & 2.5 & 2.67 & 3.5 & 2.67 \\
\hline Std. Deviation & 0.718 & 0.329 & 0.549 & 0.595 & 0.379 & 0.489 \\
\hline \multicolumn{7}{|c|}{ Personal Assessment (6 Criteria) } \\
\hline Average & 3.763 & 3.738 & 3.745 & 4.175 & 4.298 & 4.22 \\
\hline Maximum & 3.86 & 3.81 & 3.86 & 4.33 & 4.43 & 4.43 \\
\hline Minimum & 3.64 & 3.67 & 3.64 & 4 & 4.07 & 4 \\
\hline Std. Deviation & 0.101 & 0.646 & 0.156 & 0.157 & 0.14 & 0.081 \\
\hline
\end{tabular}

Traditional critics of student evaluations bias because of the instructor's gender; age; race; or national origin do not apply in this case because the same instructor delivered the course before and after development.

The new course delivery approach affected also the student performance measured in their grades. Table 3 below shows the distribution of student grades before and after the course development:

Table 3: Student Results Before and After the Course Development

\begin{tabular}{ccccccccccc}
\hline Student Grades & $\mathbf{A}$ & $\mathbf{B}^{+}$ & $\mathbf{B}$ & $\mathbf{C}^{+}$ & $\mathbf{C}$ & $\mathbf{D}^{+}$ & $\mathbf{D}$ & $\mathbf{F}$ & FA & Total \\
\hline Before Development: & & & & & & & & & \\
\hline Female Students (No.) & 1 & 2 & 2 & 1 & 1 & 1 & 2 & 2 & 2 \\
Female Students (\%) & 7 & 14 & 14 & 7 & 7 & 7 & 14 & 14 & 14 & 100 \\
\hline Male Students (No.) & 3 & 2 & 4 & 1 & 5 & 5 & 3 & 4 & 3 & 30 \\
Male Students (\%) & 10 & 7 & 13 & 3 & 17 & 17 & 10 & 13 & 10 & 100 \\
\hline \hline Total Students (No.) & 4 & 4 & 6 & 2 & 6 & 6 & 5 & 6 & 5 & 44 \\
Total Students (\%) & $\mathbf{9}$ & $\mathbf{9}$ & $\mathbf{1 4}$ & $\mathbf{5}$ & $\mathbf{1 4}$ & $\mathbf{1 4}$ & $\mathbf{1 1}$ & $\mathbf{1 4}$ & $\mathbf{1 1}$ & $\mathbf{1 0 0}$ \\
\hline After Development: & & & & & & & & & & \\
\hline Female Students (No.) & 7 & 7 & 4 & 2 & 2 & 3 & 1 & 1 & - & 27 \\
Female Students (\%) & 26 & 26 & 15 & 7 & 7 & 11 & 4 & 4 & - & 100 \\
\hline \hline Male Students (No.) & 4 & 2 & 4 & 3 & 1 & - & 1 & 1 & 1 & 17 \\
Male Students (\%) & 24 & 12 & 24 & 18 & 6 & - & 6 & 6 & 6 & 100 \\
\hline \hline Total Students (No.) & 11 & 9 & 8 & 5 & 3 & 3 & 2 & 2 & 1 & 44 \\
Total Students (\%) & $\mathbf{2 5}$ & $\mathbf{2 0}$ & $\mathbf{1 8}$ & $\mathbf{1 1}$ & $\mathbf{7}$ & $\mathbf{7}$ & $\mathbf{5}$ & $\mathbf{5}$ & $\mathbf{2}$ & $\mathbf{1 0 0}$ \\
\hline \hline
\end{tabular}


Table 3 indicates a significant progress in student performance after the course development. The percentage of students passed the course in total increased from 75 to $93 \%$. The percentage of students withdrew from the course decreased from 11 to $2 \%$. Excellent students increased from 9 to $25 \%$.

It can be argued that the reason that led to such improvement is the change to the active learning techniques and the increased attention paid to student skills related to the use of technology inside and outside the classroom.

\section{Summary and Conclusion:}

A significant change occurred in the United Arab Emirates University towards active learning based on the utilization of technology and web based education. During the period 2001 to 2005, the accounting department developed $60 \%$ of its courses to be delivered according to the new approach.

The course "Advanced Accounting" was developed to use four active learning techniques (1) engaged learning; (2) cooperative learning; (3) case-based learning; and (4) project-based learning.

The new course delivery approach requires students' use of laptops both outside and inside the classroom. Outside the classroom, they use the laptop to get the course materials from the course BB site; communicate with each other to solve group assignments through the email, and with the instructor through the digital drop box; and to get financial information related to designated companies to prepare the ongoing projects. Inside the classroom, students use the laptop to take on line quizzes; explore the net to find the latest accounting pronouncements; submit their group case answers; and to take class notes.

Application of the new course delivery approach results in more concentration on the student in the class and on activities in the grading policy. Student activities are assigned more than half of the lecture time and $50 \%$ of the total course grade. The outcome of the learning process had a significant change as a result of the course development. Student evaluations reflected more satisfaction and student grades considerably improved.

\section{REFERENCES}

1. Akan, O. H. (2005). Concrescent Conversations: Generating a Cooperative Learning Experience in Principles of Management-A Postmodern Analysis. Journal of Education for Business, 80(1), 214-217.

2. Allen, B. S., Otto, R. G., \& Hoffman, B. (2000). Case based learning: A review of the literature on its outcomes and implementation issues. Academic Medicine, 68, 52-81.

3. American Institute of Certified Public Accountants (AICPA). (1998). CPA Vision: 2011 and Beyond, AICPA. New York.

4. American Institute of Certified Public Accountants (AICPA). (1999). Fostering changes in curriculum and teaching methods. Journal of Accountancy [On-line]. Available: http://www.aicpa

5. Ashraf, M. (2004). A Critical Look at the Use of Group Projects as a Pedagogical Tool. Journal of Education for Business, 79(1), 213-216.

6. Bartlett, R. L. (1995a). Attracting "otherwise bright students" to Economics 101. American Economic Review, 85(2), Papers and proceedings of the 107th annual meeting of the American Economic Association, 362-366.

7. Bartlett, R. L. (1995b). A flip of the coin-A roll of die-An answer to the free-rider problem in economic instruction. Journal of Economic Education, 26(2), 131-139.

8. Basile, A. \& D’Aquila, J. (2002), An Experimental Analysis of Computer-Mediated Instruction and Student Attitudes in a Principles of Financial Accounting Course. Journal of Education for Business, 77(1), PP. 137143.

9. Batra, M. M., Walvoord, B. E., \& Krishnan, K. S. (1997). Effective pedagogy for student-team projects. Journal of Marketing Education, 19, 26-42.

10. Bowen, H. K., Clark, K. B., Holloway, C. A., \& Wheelwright, S. C. (1994). Make project the school for leaders. Harvard Business Review, 72(5), 131-140. 
11. Calderon, T. G. \& Green, B. P. (1997). Use of Multiple Information Types in Assessing Accounting Faculty Teaching Performance. Journal of Accounting Education, 15(2), 221-239.

12. Chapman, K. J. \& Sorge, C. L. (1999). Can a Simulation Help Achieve Course Objectives? An Exploratory Study Investigating Differences among Instructional Tools. Journal of Education for Business, 74(4), 225230 .

13. Comer, D. R. (1995). A model of social loafing in real work groups. Human Relations, 48(6), 647-667.

14. Dabbagh, N. \& Denisar, K. (2005). Assessing Team-Based Instructional Design Problem Solutions of Hierarchical Versus Heterarchical Web-Based Hypermedia Cases. Educational Technology Research and Development, 53(2), 5- 23.

15. Johnson, D. W., Johnson, R. T., Holubec, E. J., \& Roy, P. (1984). Circles of learning: Cooperation in the classroom. Alexandria, VA: Association for Supervision and Curriculum Development.

16. Kerr, N. L. (1983). Motivation losses in small groups: A social dilemma analysis. Journal of Personality and Social Psychology, 45(4), 819-828.

17. Larreche, J. (1987). On Simulations in Business Education and Research, Journal of Business Research, 15, 559-571.

18. McCorkle, D. E., Diriker, M. F., \& Alexander, J. F. (1992). An involvement-oriented approach in a mediumsized marketing principles class. Journal of Education for Business, 67(4), 197-205.

19. McKinney, K. \& Graham-Buxton, M. (1993). The uses of collaborative learning groups in the large class: Is it possible? Teaching Sociology, 21(4), 403-408.

20. Moore, R. L. (1998). Teaching introductory economics with a collaborative learning lab component. Journal of Economic Education, 29(4), 321-329.

21. Peluchette, J. V. \& Rust, K. A. (2005). Technology Use in the Classroom: Preferences of Management Faculty Members. Journal of Education for Business, 80(1), 200-205.

22. Rau, W. \& Heyl, B. (1990). Humanizing the college classroom: Collaborative learning social organization among students. Teaching Sociology, 18(2), 141-155.

23. Read, W. J., Rama, D. V., \& Raghunandan, K. (2001). The Relationship Between Student Evaluations of Teaching and Faculty Evaluations, Journal of Education for Business, 76(1), 189-192.

24. Slavin, R. E. (1988). Cooperative learning and student achievement. Educational Leadership, 46(2), $31-33$.

25. Stepich, D. A., Ertmer, P. A., \& Lane, M. M. (2001). Problem-solving in a case-based course: Strategies for facilitating coached expertise. Educational Technology Research and Development, 49(3), 53- 69.

26. Strong, J. T. \& Anderson, R. E. (1990). Free riding in group projects: Control mechanisms and preliminary data. Journal of Marketing Education, 12(2), 61-67.

27. Wallace, J. J. \& Wallace, W. A. (1998). Why the Costs of Student Evaluations Have Long Since Exceeded Their Value, Issues in Accounting Education, May, 443-448.

28. Washbush, J. \& Gosen, J. (2001). An Exploration of Game-derived Learning in Total Enterprise Simulations, Simulations \& Gaming, 32(3), 281-296.

29. Wolfe, J. (1997). The Effectiveness of Business Games in Strategic Management Course Work, Simulations \& Gaming, 28(4), 360-376.

30. Wolfe, J. \& Luethge, D. J. (2003). The Impact of Involvement on Performance in Business Simulations: An Examination of Goosen's “Know Little” Decision-Making Thesis. Journal of Education for Business, 78(3), 69-74.

31. Welty, W. (1989). Discussion method teaching. Change, July/August, 40- 49.

32. Williams, D. L., Beard, J. D., \& Rymer, J. (1991). Team projects: Achieving their full potential. Journal of Marketing Education, 13(2), 45-53. 